\title{
Influence of hydrogen cyanide-producing rhizobacteria in controlling the crown gall and root-knot nematode, Meloidogyne incognita
}

\author{
A. F. Abd El-Rahman*, Hanan A. Shaheen, Rabab M. Abd El-Aziz and Dina S. S. Ibrahim
}

\begin{abstract}
Out of 39 isolates of rhizobacteria, recovered from economic plants grown in 8 locations in Egypt, 6 isolates were able to produce Hydrogen Cyanide (HCN). 165 rRNA sequence analysis identified these isolates as: Pseudomonas japonica strain NBRC 103040, Bacillus megaterium strain CtST3.5, Pseudomonas sp. strain Gamma-81, P. tolaasii strain ATCC 33618, P. chlororaphis strain Lzh-T5, and P. mosselii strain CV25. These HCN producers were able to inhibit growth of Agrobacterium tumefaciens and affect viability of Meloidogyne incognita juveniles in vitro. The isolates of $P$. japonica and Pseudomonas sp. Gamma-81 prevented the gall formation on tomato plants by A. tumefaciens, regardless of the presence of $M$. incognita. The isolates of $B$. megaterium, P. chlororaphis, P. tolaasii, and P. mosselii decreased the weight and number of galls produced by $A$. tumefaciens in the presence or absence of $M$. incognita. The $6 \mathrm{HCN}$ producers decreased the population of $M$. incognita and the number of nematode galls than the positive control, when used against $M$. incognita. A similar effect was achieved against mixed infections with $M$. incognita and $A$. tumefaciens. The HCN-producing rhizobacteria, in the presence of $A$. tumefaciens and/or $M$. incognita, caused obvious increment in all growth parameters of tomato than the negative control and healthy plants. The only exception was found in case of Pseudomonas sp. Gamma-81 against M. incognita and against mixed infection, where growth parameters of tomato were decreased. Although the isolates were naturally isolated from the rhizosphere of economic plants, it must be cautiously considered since the isolate identified as $P$. japonica has been reported as a human pathogen. Also, P. tolaasii was reported causing a bacterial blotch on cultivated mushrooms under certain environmental conditions. Further investigations are needed.
\end{abstract}

Keywords: Crown gall, Root-knot nematode, Antagonistic bacteria, Hydrogen cyanide (HCN), Biological control

\section{Background}

Crown gall disease caused by Agrobacterium tumefaciens is a major bacterial disease in nurseries and orchards and is being considered one of the most important disorders that causes high losses in nurseries (Pulawska 2010). Biological control of crown gall is more effective in controlling the disease rather than chemical control (Tolba and Soliman 2013). Root-knot nematodes, Meloidogyne spp., are among the most important plant fauna that limit the productivity of many economic crops. The search for biological means for controlling root-knot

\footnotetext{
* Correspondence: aabdelrahman2012@gmail.com

Plant Pathology Research Institute, Agriculture Research Center, Giza, Egypt
}

nematodes (RKNs) is important because of inability of plants to resist most types of RKNs, and the chemical control is subject to debate due to the environmental hazards and human health damage (Mostafa et al. 2014). The interrelation between nematode densities and increasing of crown gall on the roots was reported for many crops references. Occurrence of wounds by nematodes allows incorporation of T DNA (the transferred DNA of the tumor-inducing (Ti) plasmid) of bacteria into the genome of plant cell and development of crown gall disease (Rubio-Cabetas et al. 2001).

Cyanide forms stable complexes with the essential elements $\left(\mathrm{Cu}^{2+}, \mathrm{Fe}^{2+}\right.$, and $\left.\mathrm{Mn}^{2+}\right)$ for the protein function and therefore is considered a toxic substance to most living 
organisms. Hydrogen cyanide $(\mathrm{HCN})$ is a volatile secondary metabolite that is synthesized by many rhizobacteria and has a powerful effect on many organisms. HCN inhibits the electron transport and disrupts the energy supply to the cell, which leads to death of living organisms. Many bacterial genera have the ability to produce $\mathrm{HCN}$ including species of Alcaligenes, Aeromonas, Bacillus, Pseudomonas, and Rhizobium (Alemu 2016).

The ability of some bacterial strains to control nematodes was attributed to their ability to produce $\mathrm{HCN}$. Moreover, a direct influence of contact between HCNproducing bacteria and the nematode is essential in the effective control of target nematode (Siddiqui et al. 2006). HCN may affect plant establishment or inhibit development of plant disease, with great potential for controlling plant bacterial diseases (Lanteigne et al. 2012). Some studies have questioned of $\mathrm{HCN}$ based on the lack of correlation of the level of $\mathrm{HCN}$ produced by rhizobacteria with the biocontrol effects in vitro. These studies have suggested that $\mathrm{HCN}$ does not act directly in the process of biocontrol, but involved in geochemical processes in the substrate (e.g., chelation of metals) leading to an indirect increase in the nutrients availability for the rhizobacteria and their plant hosts (Rijavec and Lapanje 2016).

The purposes of this work were (1) to isolate and identify $\mathrm{HCN}$-producing rhizobacteria from different locations in Egypt, screen the ability of these rhizobacteria in inhibiting A. tumefaciens, and evaluate their influence on Meloidogyne incognita in vitro; (2) to study the correlation of HCN levels produced by rhizobacteria with the biocontrol effects in vitro; and (3) to study the influence of these $\mathrm{HCN}$-producing rhizobacteria on the growth of tomato plant, the crown gall disease, the rootknot nematode infection, and the mixed infection by these two pathogen in vivo.

\section{Materials and methods}

\section{Sources of the pathogens}

The crown gall bacterium, A. tumefaciens (virulent isolate), was previously isolated from peach and identified by Abd El-Rahman (2012). The pathogenicity test was re-performed to check virulence. In order to confirm the identification, the $16 \mathrm{~S}$ rDNA analysis was used. The sequencing process was conducted at the Potato Brown Rot Project laboratories (Giza, Egypt), using forward primer (U968-f) 5'-AACGCGAAGAACCTTAC-3' and reverse primer (L1401-r) 5'CGGTGTGTACAAGACCC-3' as described by Farag et al. (2017). The RKN, M. incognita inoculum, was obtained from Nematode Diseases Research Department, Plant Pathology Research Institute, Agricultural Research Center (ARC), Giza, Egypt.

\section{Isolation of rhizobacteria}

Rhizobacteria were isolated from rhizosphere of different crops from 8 locations in Egypt. Serial dilution plate count technique was followed, using soil adhering to the roots of screened plants as described by Kifle and Laing (2016). Nutrient glucose agar and King's B agar media were used for the isolation of bacteria. The plates were incubated at $28^{\circ} \mathrm{C}$ for 3 days. The separate colonies were selected and stored as pure cultures.

\section{Screening hydrogen cyanide ( $\mathrm{HCN})$ produced by rhizobacterial isolates}

Assessment of $\mathrm{HCN}$ produced by rhizobacterial isolates was carried out. Appropriate amount of each isolate was inoculated in 250-ml flask (3 flasks/isolate), containing King's B broth medium $(100 \mathrm{ml})$ amended with $4.4 \mathrm{~g} / \mathrm{l}$ glycine. Non-inoculated flasks were used as a control. Sterile filter paper strip was dipped in picric acid solution ( $0.5 \%$ picric acid in $2 \%$ sodium carbonate) and was attached to the neck of the flask. The flask was plugged and sealed off with Parafilm. Incubation was made at $\left(28 \pm 2{ }^{\circ} \mathrm{C}\right)$ for 4 days, with shaking at $140 \mathrm{rpm}$. A change in color of the filter paper strips from yellow to light brown, brown, or brick red was recorded as weak $(+)$, moderate $(++)$, or strong $(+++)$ reaction, respectively. No change in color was recorded as a negative (-) reaction (Abd El-Rahman and Shaheen 2016).

\section{Identification of selected isolates of rhizobacteria}

Identification of selected rhizobacteria was made, using 16S rRNA analysis at Sigma Scientific Services Co., Giza, Egypt, as described by Abd El-Ghany et al. (2017). DNA extraction was made, using of GenJet ${ }^{\text {Tix }}$ genomic DNA purification Kit (ThermoK0721), according to the manufacturer's protocol by gram-negative bacteria genomic DNA purification protocol. PCR was made, using Maxima Hot Start PCR Master Mix (Thermo K 1051), according to the manufacturer's protocol by using forward primer 5'-AGAGTTTGATCCTGGCTCAG-3' and reverse primer 5'-GGTTACCTTGTTACGACTT-3' (Eden et al. 1991). The PCR products were purified using GeneJet $^{\text {tw }}$ PCR purification Kit (Thermo K0701). Finally, the PCR products were sequenced, using ABI $3730 \times 1$ DNA sequencer, using forward and reverse primers. Obtained sequences were compared to those available in the database GeneBank network services at http://blast.ncbi.nlm. nih.gov/Blast.cgi for significant alignments.

Quantitative assay of hydrogen cyanide (HCN) production Suspension $\left(3 \mathrm{ml}\right.$ of $\left.10^{6} \mathrm{cfu} / \mathrm{ml}\right)$ of each bacterial isolate was inoculated in $(250 \mathrm{ml})$ flask containing King's B broth medium $(100 \mathrm{ml})$ amended with glycine $(4.4 \mathrm{~g} / \mathrm{l})$. Three replicates were used for each tested isolate. Noninoculated flasks were used as control. Strips of filter 
paper $(10 \times 0.5 \mathrm{~cm})$ were soaked in alkaline picrate solution and kept hanging to the neck of the flask (one strip for each flask). The flasks was plugged and sealed off with Para film. Three replicates were used for each isolate. After incubation at $28 \pm 2{ }^{\circ} \mathrm{C}$ for 4 days (with shaking at $140 \mathrm{rpm}$ ), the color of sodium picrate strips was changed to a reddish compound in proportion to the amount of HCN evolved. The color was eluted by placing the changed filter paper in a test tube containing $10 \mathrm{ml}$ of distilled water, and its absorbance was read by the UV/Visible spectrophotometer (MODEL:2000 UV UNICO INSTRUMENTS CO., LTD,USA) at $625 \mathrm{~nm}$. Distilled water was used to adjust the zero absorbance reading at $625 \mathrm{~nm}$ before reading (Reetha et al. 2014).

Preparation of $A$. tumefaciens and rhizobacteria inoculum Each bacterial isolate was grown in King's $B$ agar medium plates for $48 \mathrm{~h}$ at $28{ }^{\circ} \mathrm{C}$, and then, bacterial growth was harvested into a saline solution $(0.85 \%$ $\mathrm{NaCl}$ ) to prepare bacterial suspension that was adjusted to $10^{8} \mathrm{cfu} / \mathrm{ml}$.

\section{Preparation of $M$. incognita inoculum}

Fresh second-stage juveniles $\left(\mathrm{J}_{2}\right)$ of $M$. incognita were obtained from pure culture maintained on coleus ( $\mathrm{Co}$ leus blumei) roots. Roots were incubated for 5-7 days in a modified Baermann method for hatching at room temperature (Ibrahim et al. 2013).

\section{In vitro antagonistic determination of rhizobacteria} against gall-forming bacteria and second-stage juveniles Certain rhizobacterial isolates were screened for their ability to inhibit the growth of A. tumefaciens on KBA medium plates. A loopful of the tested isolate $(24 \mathrm{~h}$ old culture) was placed at the center of inoculated plate with A. tumefaciens, using $3 \mathrm{ml}$ of $10^{8} \mathrm{cfu} / \mathrm{ml}$ suspension for flask containing $250 \mathrm{ml}$ medium. Three replicates were used for each tested isolate. The plates were incubated at $28^{\circ} \mathrm{C}$ for $48 \mathrm{~h}$, and the inhibition zone diameter was measured to the nearest millimeter (Abd El-Rahman and Shaheen 2016).

Detrimental effect of bacterial isolates against $\left(\mathrm{J}_{2}\right)$ of M. incognita was evaluated. One milliliter $\left(10^{8} \mathrm{cfu} / \mathrm{ml}\right)$ of bacterial isolates was added to $4 \mathrm{ml}$ of $M$. incognita suspension containing 100 juveniles $\left(\mathrm{J}_{2}\right)$ in a Petri dish $(6$ $\mathrm{cm}$ diameter). One milliliter of saline solution $(0.85 \%$ $\mathrm{NaCl}$ ) instead of bacterial suspension was used as control. Three replicates from each treatment were made. All dishes were sealed off with Parafilm and kept at the room temperature $\left(30{ }^{\circ} \mathrm{C}\right)$. The dishes were examined under a microscope after 24,48 , and $72 \mathrm{~h}$ and then left for 7 days and checked for the last time. The number of surviving and dead larvae was counted. Percentage mortality due to the effect of bacterial isolate was calculated as follows:

Mortality $\%=[$ (number of live nematode juveniles in control - number of live nematode juveniles in treatment)/number of live nematode juveniles in control] $x$ 100 (Abdel-Salam et al. 2018).

\section{In vivo experiment}

The effect of selected isolates of rhizobacteria on growth of tomato plant, crown gall disease, the RKN, and the mixed infection by these 2 diseases was tested in a greenhouse $\left(22 \pm 3{ }^{\circ} \mathrm{C}\right)$. Each pot $(20 \mathrm{~cm}$ in diameter $)$ containing $800 \mathrm{~g}$ clean soil (clay to sand to compost at 2: 1:1 ratio) was planted by one of 3 weeks old tomato (cv. Super Strain B) seedlings. The first group of pots was allocated to study the effect of rhizobacteria on crown gall disease, the second one for the effect of rhizobacteria on RKN, and the third was to test the effect of rhizobacteria on the mixed infection with crown gall bacteria and root-knot nematode. Pots were arranged in a completely randomized design and treated as needed experimentally. Five replicates per treatment were used. All treatments were run 10 days after planting. Five pots were left free of nematode, $A$. tumefaciens, and rhizobacteria as un-inoculated (healthy plant) treatment for the 3 experiment groups. Five pots pricked at the crown region of tomato plants were used as negative control for the first and third experiment groups.

For the first group, the seedlings were pricked at the crown region of tomato plants, and the soil was drenched with suspension $\left(10^{8} \mathrm{cfu} / \mathrm{ml}\right)$ of bioagent $(100$ $\mathrm{ml} / \mathrm{pot})$ along with suspension $\left(10^{8} \mathrm{cfu} / \mathrm{ml}\right)$ of $A$. tumefaciens isolate $(100 \mathrm{ml} / \mathrm{pot})$ together at the same time. Five inoculated pots with A. tumefaciens were served as a positive control. For the second group, the soil was drenched by the suspension $\left(10^{8} \mathrm{cfu} / \mathrm{ml}\right)$ of bioagent at the rate of $100 \mathrm{ml} /$ pot (five pots treated with oxamyl 0.3 $\mathrm{ml} /$ pot was used for comparison), and after $48 \mathrm{~h}$, inoculation was made with 2000 s-stage juveniles/plant of $M$. incognita. Five inoculated pots with $M$. incognita were served as a positive control. The same treatments in the first group were prepared as a third trial, and after $48 \mathrm{~h}$, the seedlings were inoculated by 2000 of the secondstage juveniles/plant of RKN. Five inoculated pots with A. tumefaciens and $M$. incognita served as a positive control.

\section{Pathological determination}

Determination for A. tumefaciens and M. incognita syndromes were recorded after 45 days of inoculation. Weight (g) and number of galls of $A$. tumefaciens were recorded, in the first and the third groups. Percentage of decreasing in crown gall disease (PDD) was calculated from the weight and number of galls as follows: $\mathrm{PDD}=[(\mathrm{C}-\mathrm{T}(/$ 
C] $\times 100$ where $\mathrm{C}=$ weight or number of galls in control and $\mathrm{T}=$ weight or number of galls in treatment.

Nematode population in soil $(250 \mathrm{~g})$, number of developmental stages and females in roots, number of galls, and number of egg masses of $M$. incognita were recorded in the second and the third groups of treatments. The final population (Pf) of nematode was calculated as follows: nematode population in soil + no. of developmental stages + no. of females. Reproduction factor (RF) was calculated as follows: final population (Pf) in treatment/no. of treatment initial inoculum. The percentage of reductions in nematode population (red \%) was calculated as follows: $\operatorname{Red} \%=\left[\left(\mathrm{Pf}_{\mathrm{c}}-\mathrm{Pf}_{\mathrm{t}}\right) / \mathrm{Pf}_{\mathrm{c}}\right] \times 100$ where $\mathrm{Pf}_{\mathrm{c}}=$ the final population in control and $\mathrm{Pf}_{\mathrm{t}}=$ the final population (Pf) in treatment. Root gall index (RGI) or egg masses index (EI) was determined according to the scale given by Taylor and Sasser (1978) as follows: 0 = no galls or egg masses, $1=1-2$ galls or egg masses, $2=3-10$ galls or egg masses, $3=11-30$ galls or egg masses, $4=31-100$ galls or egg masses, and $5=$ more than 100 galls or egg masses.

\section{Plant growth parameters}

Growth parameters (shoot length, shoot fresh weight, and root fresh weight) of tomato plants were recorded after 45 days of inoculation at all treatments. The dry weight of the whole plant is estimated after drying the vegetative growth and roots of plant in oven at $100^{\circ} \mathrm{F}$ $\left(37.8^{\circ} \mathrm{C}\right)$ overnight.

\section{Statistical analysis}

Completely randomized design was used in all in vitro and in vivo pot experiments. Collected data were subjected to analysis of variance. Comparisons among treatment means were made, using Duncan multiple range test at 0.05 level of probability, using MINITAB software (version 16, MINITAB, Inc., State College, PA).

\section{Results and discussion \\ Confirmation the identity of the crown gall bacterium Agrobacterium tumefaciens (virulent isolate)}

Bacterial isolate, previously identified as A. tumefaciens on the basis of the traditional bacteriological methods, was further confirmed by $16 \mathrm{~S}$ rDNA analysis. The results showed that $A$. tumefaciens (virulent isolate) showed $(98.41 \%)$ similarity with $A$. tumefaciens strain IAM 12048 and A. tumefaciens strain NCPPB2437. Distance tree, using rRNA type strains/Bacteria and Archaea_16S_ribosomal RNA sequences database, is illustrated in (Fig. 1).

\section{Ability of rhizobacteria to produce hydrogen cyanide (HCN)}

Many bacterial genera had the ability to produce $\mathrm{HCN}$ embracing many species of Alcaligenes, Aeromonas, $\mathrm{Ba}$ cillus, Pseudomonas, and Rhizobium (Alemu 2016). Thirty-nine isolates of rhizobacteria, recovered from different locations and different crops in Egypt, were tested for their ability to produce hydrogen cyanide $(\mathrm{HCN})$. Only 6 isolates were able to produce HCN. The $6 \mathrm{HCN}$ producing isolates were isolated from rhizosphere soil of

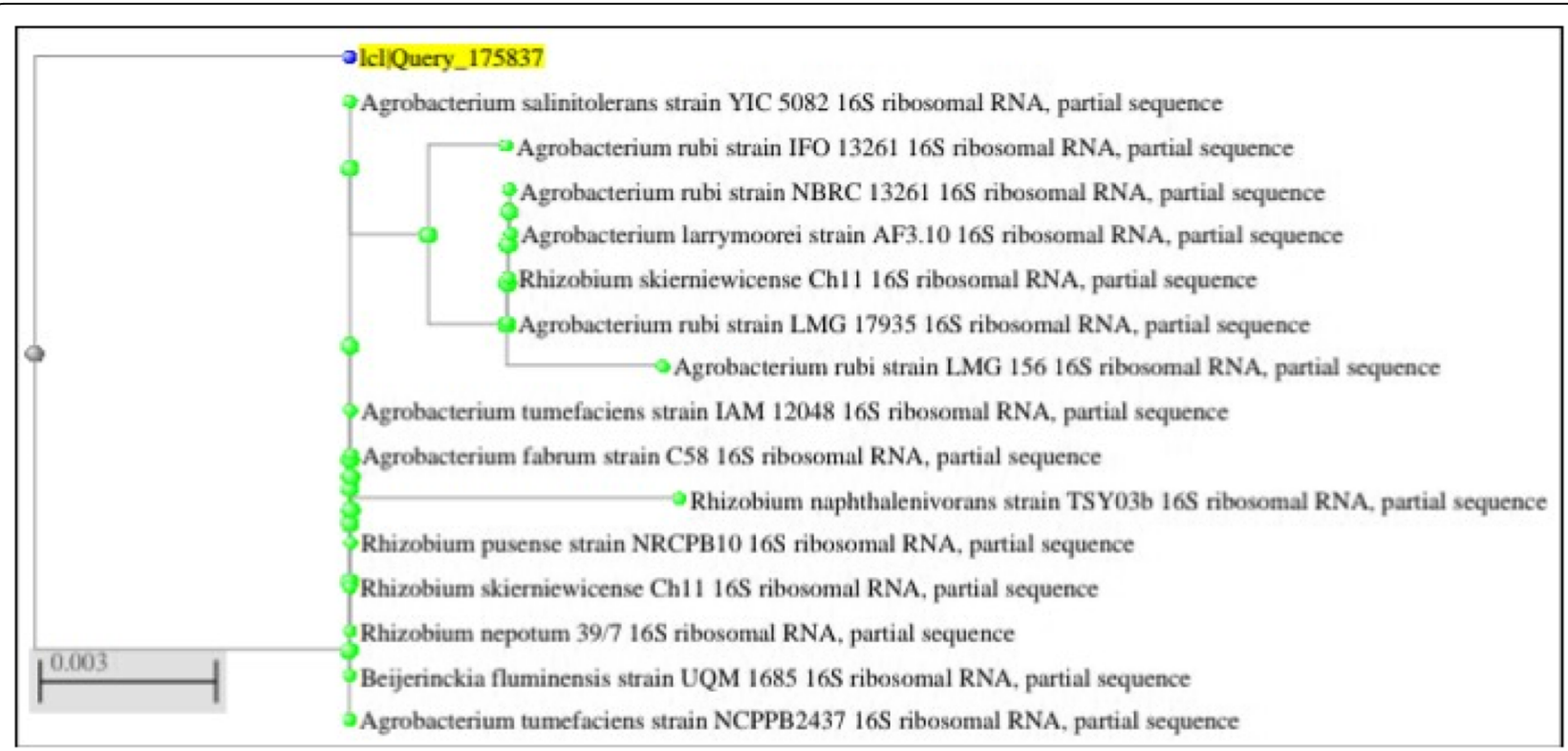

Fig. 1 Distance tree using rRNA type strains/bacteria and Archaea_16S_ribosomal RNA sequences database. Icl|Query _ 175837 refers to the A. tumefaciens (virulent isolate) 
guava plants grown in Behiera governorate (BR11 and BR13), peach plants grown in Giza governorate (GA21), potato plants grown in Ismailia governorate (SW1 and SW4), and corn plants grown in Beni-Seuf governorate (BW3). A strong $(+++) \mathrm{HCN}$ production was recorded by the isolate BR13 from guava; while a moderate $(++)$ reaction was recorded by BR11, GA 21, and SW1 from guava, peach, and potato, respectively. A weak $(+)$ reaction was recorded by BW3 and SW4 from corn and potato, respectively (Table 1 ).

\section{S rRNA analysis}

Results of DNA sequence, obtained from 16S rRNA analysis of the $6 \mathrm{HCN}$ isolates collected from different plant rhizosphere and locations in Egypt compared to DNA sequence available at the NCBI database, are shown in (Table 2). Comparison of the DNA sequences of SW1, BW3, SW4, BR 11, BR 13, and GA 21 with DNA sequence in the NCBI database identified these isolates as: Pseudomonas japonica strain NBRC 103040, Bacillus megaterium strain CtST3.5, Pseudomonas sp. strain Gamma-81, P. tolaasii strain ATCC 33618, P. chlororaphis strain Lzh-T5, and $P$. mosselii strain CV25 by percent of 97, 98, 100, 99, 99, and 99), respectively.

\section{Quantitative assay of HCN production by bacterial isolates}

Quantitative assay of $\mathrm{HCN}$ production by bacterial isolates showed that $P$. chlororaphis greatly produced $\mathrm{HCN}$ and recorded the maximum absorbance value of (0.047), followed by $P$. mosselii, $P$. tolaasii, and $P$. japonica, which recorded absorbance values of $0.027,0.024$, and $0.020)$, respectively. The lowest absorbance values $(0.002$ and 0.005 ) were recorded by $B$. megaterium and Pseudomonas sp. Gamma-81, respectively (Table 3).
Efficacy of HCN-producing rhizobacteria on growth of $A$. tumefaciens and $M$. incognita in vitro

The results reported herein (Table 4) showed that the 6 isolates of $\mathrm{HCN}$-producing rhizobacteria could inhibit the growth of $A$. tumefaciens in vitro. The inhibition zone diameter ranged from 13.7 to $49.7 \mathrm{~mm}$. The maximum inhibition $(49.7 \mathrm{~mm})$ was recognized by the $P$. japonica isolate, followed by P. mosselii, Pseudomonas sp. strain Gamma-81., P. chlororaphis, P. tolaasii, and B. megaterium, which recorded 33.7, 30.7, 25.7, 14.3, and $13.7 \mathrm{~mm})$, respectively.

Efficacy of 6 isolates of $\mathrm{HCN}$-producing rhizobacteria on $M$. incognita under laboratory conditions was shown in (Table 5) as a percentage of mortality of 100 juveniles $\left(\mathrm{J}_{2}\right)$ of $M$. incognita after different exposure periods to bacterial suspension. The results showed that P. japonica, $P$. chlororaphis, and $P$. mosselii had influenced $\mathrm{J}_{2}$ survival after $24 \mathrm{~h}$ incubation. The mortality rate of juveniles reached 24.3, 38.0, and 23.0\%, respectively. By increasing the exposure time, all bacterial isolates affected the life of nematode juveniles. The rate of mortality of the juveniles ranged from 23.7 to $49.2 \%$ and from 32.3 to $68.6 \%$ after 48 and $72 \mathrm{~h}$, respectively. After 7 day of incubation, the maximum mortality percent was achieved by $P$. chlororaphis isolate, recording 96.4 with significant differences with Pseudomonas sp. Gamma-81, P. mosselii, P. japonica, B. megaterium, and P. tolaasii, which recorded mortality percent of $63.9,54.6,51.8$, 43.9, and 42.8, respectively.

In this regard, some studies have questioned the biocontrol effect of $\mathrm{HCN}$ based on the findings on the lack of correlation between the level of $\mathrm{HCN}$ produced by rhizobacteria and the antagonistic effects in vitro (Rijavec and Lapanje 2016). From these results, the correlation of the level of $\mathrm{HCN}$, produced by rhizobacteria with the biocontrol effects in vitro, was more clearly in the case of $M$. incognita nematode than the case of $A$.

Table 1 Source of rhizobacterial isolates and their tentative ability to produce HCN

\begin{tabular}{|c|c|c|c|c|c|c|}
\hline Governorate & Location & $\begin{array}{l}\text { Type of } \\
\text { crop }\end{array}$ & $\begin{array}{l}\text { No. of tested } \\
\text { isolates }\end{array}$ & $\begin{array}{l}\text { No. of HCN producing } \\
\text { isolates }\end{array}$ & $\begin{array}{l}\text { HCN producing isolate } \\
\text { code }\end{array}$ & $\begin{array}{l}\text { HCN producing } \\
\text { reaction* }\end{array}$ \\
\hline Beni Suef & Al-Wasta & Corn & 4 & 1 & BW3 & + \\
\hline Monufia & $\begin{array}{l}\text { Cairo-Alex. desert Rd(Dina } \\
\text { farms) }\end{array}$ & Corn & 5 & 0 & - & - \\
\hline Minya & Mallawi & Onion & 4 & 0 & - & - \\
\hline \multirow[t]{2}{*}{ Beheira } & \multirow[t]{2}{*}{ Rashid } & \multirow[t]{2}{*}{ Guava } & \multirow[t]{2}{*}{7} & \multirow[t]{2}{*}{2} & BR11 & ++ \\
\hline & & & & & BR13 & +++ \\
\hline Beheira & International Coastal Rd & Apple & 4 & 0 & - & - \\
\hline Beheira & Abu Al Matamir & Banana & 4 & 0 & - & - \\
\hline Giza & Abu Rawash & Peach & 5 & 1 & GA 21 & ++ \\
\hline \multirow[t]{2}{*}{ Ismailia } & \multirow[t]{2}{*}{ Wadi El-Mollak } & \multirow[t]{2}{*}{ Potato } & \multirow[t]{2}{*}{6} & \multirow[t]{2}{*}{2} & SW1 & ++ \\
\hline & & & & & SW4 & + \\
\hline
\end{tabular}

*Negative $(-)$, weak $(+)$, moderate $(++)$ or strong $(+++)$ reaction 
Table 2 Molecular identification of six plant rhizosphere isolates using 16S rRNA gene sequence

\begin{tabular}{|c|c|c|c|c|c|c|}
\hline Isolates code. & Identification by $16 \mathrm{~S}$ rRNA sequence analysis & Max score & Total score & Query cover & E. value & Max ident \\
\hline SW1 & Pseudomonas japonica strain NBRC 103040 & 1524 & 1524 & $99 \%$ & 0.0 & $97 \%$ \\
\hline BW3 & Bacillus megaterium strain CtST3.5 & 1334 & 1334 & $99 \%$ & 0.0 & $98 \%$ \\
\hline SW4 & Pseudomonas sp. strain Gamma-81 & 1314 & 1314 & $100 \%$ & 0.0 & $100 \%$ \\
\hline BR11 & Pseudomonas tolaasii strain ATCC 33618 & 1149 & 1149 & $100 \%$ & 0.0 & $99 \%$ \\
\hline BR13 & Pseudomonas chlororaphis strain Lzh-T5 & 1528 & 7615 & $100 \%$ & 0.0 & $99 \%$ \\
\hline GA 21 & Pseudomonas mosselii strain CV25 & 1650 & 1650 & $99 \%$ & 0.0 & $99 \%$ \\
\hline
\end{tabular}

tumefaciens bacteria, although this correlation was not a complete correlation relationship in the both cases.

\section{Effect of HCN-producing rhizobacteria on incidence of crown gall on tomato plants}

Effect of 6 isolates of $\mathrm{HCN}$-producing rhizobacteria on incidence of crown gall caused by $A$. tumefaciens on tomato plants in the absence or presence of $M$. incognita after 45 days of inoculation was shown in (Table 6). Results proved that the isolates of P. japonica and Pseudomonas sp. Gamma-81 prevented completely gall formation on tomato plants in both cases. In the absence of $M$. incognita, the isolates of $B$. megaterium, $P$. chlororaphis, P. tolaasii, and P. mosselii decreased the weight of galls caused by A. tumefaciens on tomato plants by 92.1 , $67.0,60.8$, and $49.9 \%$, respectively. Also, a pronounced decrement in the number of galls by $93.3,52.0,56.0$, and $48.0 \%$ was recognized, respectively. In the presence of $M$. incognita, the isolates of $B$. megaterium, P. chlororaphis, $P$. tolaasii, and $P$. mosselii decreased the gall weight produced by $A$. tumefaciens on tomato plants by 80.2 , $81.7,64.8$, and $53.0 \%$ and decreased the number of galls by $81.7,73.9,62.5$, and $57.0 \%$, respectively. Although the isolate of $B$. megaterium showed a high ability to control crown gall disease in the absence of $M$. incognita, however, this capability was decreased significantly in the presence of $M$. incognita by $11.9 \%$ for gall weight and by $11.6 \%$ for number of galls. Meanwhile, though the isolates of $P$. tolaasii, P. chlororaphis, and P. mosselii showed a moderate ability to control crown gall in the absence of $M$. incognita, the capability increased in the

Table 3 Quantitative assay of HCN produced by bacterial isolates at $625 \mathrm{~nm}$ wavelength

\begin{tabular}{ll}
\hline Rhizobacteria & Absorbance at wavelength $625 \mathrm{~nm}$ \\
\hline P. japonica & $0.020^{\mathrm{C}}$ \\
B. megaterium & $0.002^{\mathrm{D}}$ \\
Pseudomonas sp. strain Gamma-81 & $0.005^{\mathrm{D}}$ \\
P. tolaasii & $0.024^{\mathrm{BC}}$ \\
P. chlororaphis & $0.047^{\mathrm{A}}$ \\
P. mosselii & $0.027^{\mathrm{B}}$ \\
Control & $0.001^{\mathrm{D}}$
\end{tabular}

Means in the table shared a letter are not significantly different $(p \leq 0.05)$ presence of $M$. incognita by 4.0, 14.0, and $3.1 \%$ for gall weight and by $6.5,21.9$, and $9.0 \%$ for the number of galls, respectively. This is despite the fact that $P$. chlororaphis and $P$. mosselii produced $\mathrm{HCN}$ and inhibited the growth of $A$. tumefaciens better than Pseudomonas sp. Gamma-81 in vitro. These results denoted that HCN can play a role in controlling the crown gall disease, in addition to possible other factors produced by antagonistic bacteria that are more potent in controlling the disease. There are many mechanisms that are used by Pseudomonas spp. to control plant diseases such as production of some secondary metabolites (hydrogen cyanide, Fe-chelating siderophores, and antibiotics), induction of plant defense responses and competition for nutrients (Lukkani and Reddy 2014).

\section{Effect of HCN-producing rhizobacteria on incidence of root-knot nematode on tomato plants}

The potential of some bacterial strains to control nematodes is related to their ability to produce $\mathrm{HCN}$. Moreover, a direct contact between HCN-producing bacteria and the nematode is essential in the effective control of nematode (Siddiqui et al. 2006). Data in Table 7 showed that HCN-producing rhizobacteria decreased the final population of $M$. incognita and the number of nematode galls than the positive control, when used against $M$. incognita and mixed infection with $M$. incognita and $A$. tumefaciens. The lowest final population count of nematodes (411.0 and 342.4) was recorded by P. mosselii, when used against $M$. incognita and mixed infection, respectively. The $M$. incognita and mixed infection (positive controls) recorded final population counts of 5574.0

Table 4 Effect of six isolates of HCN-producing rhizobacteria on growth of Agrobacterium tumefaciens in vitro

\begin{tabular}{ll}
\hline Rhizobacteria & Inhibition zone diameter $(\mathrm{mm})$ \\
\hline P. japonica & $49.7^{\mathrm{A}}$ \\
B. megaterium & $13.7^{\mathrm{D}}$ \\
Pseudomonas sp. Gamma-81 & $30.7^{\mathrm{BC}}$ \\
P. tolaasii & $14.3^{\mathrm{D}}$ \\
P. chlororaphis & $25.7^{\mathrm{C}}$ \\
P. mosselii & $33.7^{\mathrm{B}}$ \\
\hline
\end{tabular}

Means in the table shared a letter are not significantly different $(p \leq 0.05)$ 
Table 5 Effect of different exposure time with certain HCN-producing rhizobacteria on mortality rate of Meloidogyne incognita

\begin{tabular}{|c|c|c|c|c|c|c|c|c|}
\hline \multirow[t]{3}{*}{ Rhizobacteria } & \multicolumn{8}{|c|}{ Exposure period } \\
\hline & \multicolumn{2}{|l|}{$24 \mathrm{~h}$} & \multicolumn{2}{|l|}{$48 \mathrm{~h}$} & \multicolumn{2}{|l|}{$72 \mathrm{~h}$} & \multicolumn{2}{|l|}{7 days } \\
\hline & $\begin{array}{l}\text { No. of live } \\
\text { juveniles* }\end{array}$ & $\begin{array}{l}\text { Mortality } \\
\%^{* *}\end{array}$ & $\begin{array}{l}\text { No. of live } \\
\text { juveniles* }\end{array}$ & $\begin{array}{l}\text { Mortality } \\
\%^{* *}\end{array}$ & $\begin{array}{l}\text { No. of live } \\
\text { juveniles* }\end{array}$ & $\begin{array}{l}\text { Mortality } \\
\%^{* *}\end{array}$ & $\begin{array}{l}\text { No. of live } \\
\text { juveniles* }\end{array}$ & $\begin{array}{l}\text { Mortality } \\
\%^{* *}\end{array}$ \\
\hline P. japonica & $75.7^{B}$ & $24.3^{K}$ & $54.3^{\mathrm{EF}}$ & $44.8^{\mathrm{EFG}}$ & $52.0^{\mathrm{FGH}}$ & $45.9^{D-G}$ & $45.0^{\mathrm{GHI}}$ & $51.8^{\mathrm{CDE}}$ \\
\hline B. megaterium & $100.0^{\mathrm{A}}$ & $00.0^{\llcorner}$ & $75.0^{B}$ & $23.7^{K}$ & $65.0^{\mathrm{CD}}$ & $32.3^{\mid J}$ & $52.3^{\mathrm{FGH}}$ & $43.9^{\mathrm{EFG}}$ \\
\hline $\begin{array}{l}\text { Pseudomonas sp. } \\
\text { Gamma-81 }\end{array}$ & $100.0^{A}$ & $00.0^{L}$ & $51.0^{\mathrm{F}-1}$ & $48.1^{C-F}$ & $44.0^{\mathrm{HI}}$ & $54.2^{c}$ & $33.7^{\mathrm{JK}}$ & $63.9^{\mathrm{B}}$ \\
\hline P. tolaasii & $100.0^{A}$ & $00.0^{\mathrm{L}}$ & $73.0^{B C}$ & $25.8^{\mathrm{JK}}$ & $62.0^{\mathrm{DE}}$ & $35.4^{\mathrm{HI}}$ & $53.3^{\mathrm{EFG}}$ & $42.8^{\mathrm{FGH}}$ \\
\hline P. chlororaphis & $62.0^{\mathrm{DE}}$ & $38.0^{G H I}$ & $50.0^{\mathrm{F}-1}$ & $49.2^{C-F}$ & $30.0^{\mathrm{K}}$ & $68.6^{B}$ & $03.3^{\mathrm{L}}$ & $96.4^{\mathrm{A}}$ \\
\hline P. mosselii & $77.0^{B}$ & $23.0^{\mathrm{K}}$ & $64.0^{C D}$ & $34.9^{\mathrm{HI}}$ & $45.0^{G H I}$ & $53.2^{\mathrm{CD}}$ & $42.3^{1 J}$ & $54.6^{C}$ \\
\hline Control & $100.0^{\mathrm{A}}$ & $00.0^{L}$ & $98.3^{\mathrm{A}}$ & $00.0^{\mathrm{L}}$ & $96.0^{A}$ & $00.0^{L}$ & $93.3^{\mathrm{A}}$ & $00.0^{\mathrm{L}}$ \\
\hline
\end{tabular}

Means in the columns which marked with* or ${ }^{* *}$ shared a letter are not significantly different $(p \leq 0.05)$

and 4560.4, respectively. The nematicidal oxamyl recorded a final population count of 288.0, when used as a comparison treatment against $M$. incognita.

The lowest population counts of nematode in soil (396.0 and 324.0) were recorded by $P$. mosselii, when used against M. incognita and mixed infection, respectively. The M. incognita and mixed infection (positive controls) recorded population counts in soil of 5412.0 and 4456.0, respectively. Oxamyl recorded a population count in soil of 244.0 in soil, when used as a comparison treatment against $M$. incognita.

The number of nematode galls decreased by using $\mathrm{HCN}$-producing rhizobacteria against $M$. incognita and mixed infection than the positive control. The lowest numbers of galls (11.2 and 11.0) were recorded by $P$. japonica and $P$. mosselii, when used against $M$. incognita and mixed infection, respectively. The $M$. incognita and mixed infection (positive controls) recorded a number of galls of 63.8 and 53.0, respectively. Oxamyl recorded a number of galls (21.6), when used as a comparison treatment against $M$. incognita.

These results are remarkably consistent with the results obtained in the laboratory, where a quantitative assay of producing $\mathrm{HCN}$ by tested bacterial isolates showed that $P$. japonica, $P$. tolaasii, $P$. chlororaphis, and $P$. mosselii strongly produced $\mathrm{HCN}$ compared to $B$. megaterium and Pseudomonas sp. Gamma-81. Only $P$. japonica, $P$. chlororaphisi, and $P$. mosselii isolates affected the life of juveniles $\left(\mathrm{J}_{2}\right)$ of $M$. incognita after $24 \mathrm{~h}$ of incubation. This conclusion is clear in spite of the observation that isolate of $P$. japonica did not give good results that match with laboratory experiments.

\section{Effect of HCN-producing rhizobacteria on growth parameters of tomato plants}

The 6 isolates of HCN-producing rhizobacteria in the presence of $A$. tumefaciens and/or $M$. incognita increased

Table 6 Effect of six isolates of HCN-producing rhizobacteria on incidence of crown gall disease on tomato plants in the absence or presence of Meloidogyne incognita after 45 days of inoculation

\begin{tabular}{|c|c|c|c|c|c|c|c|c|}
\hline \multirow[t]{3}{*}{ Rhizobacteria } & \multicolumn{8}{|c|}{ Incidence of crown gall disease } \\
\hline & \multicolumn{4}{|l|}{ A. tumefaciens } & \multicolumn{4}{|c|}{ A. tumefaciens $+M$. incognita } \\
\hline & $\begin{array}{l}\text { Galls weight } \\
\text { (g)/plant* }\end{array}$ & $\begin{array}{l}\text { Decreasing in } \\
\text { galls weight \%** }\end{array}$ & $\begin{array}{l}\text { No. of } \\
\text { galls/ } \\
\text { plant*** }\end{array}$ & $\begin{array}{l}\text { Decreasing in no. } \\
\text { of galls } \%^{* * * *}\end{array}$ & $\begin{array}{l}\text { Galls weight } \\
\text { (g)/plant* }\end{array}$ & $\begin{array}{l}\text { Decreasing in } \\
\text { gall weight } \%^{* *}\end{array}$ & $\begin{array}{l}\text { No. of } \\
\text { galls/ } \\
\text { plant*** }\end{array}$ & $\begin{array}{l}\text { Decreasing in no. } \\
\text { of galls } \% * * * *\end{array}$ \\
\hline P. japonica & $0.00^{G}$ & $100.0^{\mathrm{A}}$ & $0.0^{F}$ & $100.0^{\mathrm{A}}$ & $0.00^{G}$ & $100.0^{\mathrm{A}}$ & $0.0^{\mathrm{F}}$ & $100.0^{A}$ \\
\hline B. megaterium & $0.05^{\mathrm{FG}}$ & $92.1^{\mathrm{AB}}$ & $0.4^{\mathrm{EF}}$ & $93.3^{A B}$ & $0.14^{\mathrm{DEF}}$ & $80.2^{\mathrm{B}}$ & $1.4^{\mathrm{DE}}$ & $81.7^{B C}$ \\
\hline $\begin{array}{l}\text { Pseudomonas sp. } \\
\text { Gamma-81 }\end{array}$ & $0.00^{G}$ & $100.0^{\mathrm{A}}$ & $0.0^{F}$ & $100.0^{\mathrm{A}}$ & $0.00^{G}$ & $100.0^{\mathrm{A}}$ & $0.0^{\mathrm{F}}$ & $100.0^{\mathrm{A}}$ \\
\hline P. tolaasii & $0.24^{\mathrm{BCD}}$ & $60.8^{\mathrm{CDE}}$ & $2.4^{\mathrm{CD}}$ & $56.0^{\mathrm{EF}}$ & $0.25^{B C}$ & $64.8^{\mathrm{CD}}$ & $2.6^{\mathrm{CD}}$ & $62.5^{\mathrm{DE}}$ \\
\hline P. chlororaphis & $0.20^{\mathrm{CDE}}$ & $67.0^{c}$ & $2.6^{\mathrm{CD}}$ & $52.0^{\mathrm{EF}}$ & $0.13^{\mathrm{EF}}$ & $81.7^{\mathrm{B}}$ & $1.8^{\mathrm{CD}}$ & $73.9^{\mathrm{CD}}$ \\
\hline P. mosselii & $0.31^{B C}$ & $49.9^{\mathrm{E}}$ & $2.8^{C}$ & $48.0^{\mathrm{F}}$ & $0.33^{\mathrm{B}}$ & $53.0^{\mathrm{DE}}$ & $3.0^{C}$ & $57.0^{\mathrm{EF}}$ \\
\hline Control(+) & $0.61^{A}$ & $0.00^{\mathrm{F}}$ & $5.4^{B}$ & $0.0^{G}$ & $0.71^{\mathrm{A}}$ & $0.00^{\mathrm{F}}$ & $7.0^{\mathrm{A}}$ & $0.0^{G}$ \\
\hline Control(-) & $0.00^{G}$ & - & $0.0^{F}$ & - & $0.00^{G}$ & - & $0.0^{F}$ & - \\
\hline Healthy plant & $0.00^{G}$ & - & $0.0^{\mathrm{F}}$ & - & $0.00^{G}$ & - & $0.0^{\mathrm{F}}$ & - \\
\hline
\end{tabular}

Means in the columns which marked with ${ }^{*},{ }^{* * * *}$ or ${ }^{* * * *}$ shared a letter are not significantly different $(p \leq 0.05)$ 
Table 7 Effect of six isolates of HCN-producing rhizobacteria on incidence of root-knot nematode on tomato plants in the absence or the presence of $A$. tumefaciens after 45 days of inoculation

\begin{tabular}{|c|c|c|c|c|c|c|c|c|c|c|c|}
\hline \multirow[t]{4}{*}{ Treatments } & \multirow[t]{4}{*}{ Pathogen } & \multicolumn{10}{|c|}{ Incidence of root-knot nematode disease } \\
\hline & & \multicolumn{3}{|c|}{ Nematode population in } & \multirow{3}{*}{$\begin{array}{l}\text { Final } \\
\text { population } \\
(\mathrm{Pf})\end{array}$} & \multirow{3}{*}{$\begin{array}{l}\text { Reproduction } \\
\text { factor (RF) }\end{array}$} & \multirow{3}{*}{$\begin{array}{l}\text { Reductions } \\
\text { in } \\
\text { nematode } \\
\text { population } \\
\%(\text { Red \%) }\end{array}$} & \multirow{3}{*}{$\begin{array}{l}\text { No. of } \\
\text { galls }\end{array}$} & \multirow{3}{*}{$\begin{array}{l}\text { Root } \\
\text { gall } \\
\text { index } \\
(\mathrm{RGI})\end{array}$} & \multirow{3}{*}{$\begin{array}{l}\text { No. of } \\
\text { egg } \\
\text { masses }\end{array}$} & \multirow{3}{*}{$\begin{array}{l}\text { Egg } \\
\text { masses } \\
\text { index } \\
\text { (EI) }\end{array}$} \\
\hline & & \multirow{2}{*}{$\begin{array}{l}\text { Soil } \\
(250 \mathrm{~g})\end{array}$} & \multicolumn{2}{|l|}{ Root } & & & & & & & \\
\hline & & & $\begin{array}{l}\text { Developmental } \\
\text { stages }\end{array}$ & Females & & & & & & & \\
\hline P. japonica & \multirow[t]{8}{*}{ M. incognita } & $784.0^{\mathrm{EF}}$ & $0.0^{\mathrm{E}}$ & $15.0^{G}$ & $799.0^{\mathrm{E}}$ & 0.40 & 85.7 & $11.2^{\mathrm{F}}$ & 3.0 & $12.8^{\mathrm{ABC}}$ & 3.0 \\
\hline B. megaterium & & $1808.0^{C}$ & $5.0^{\mathrm{DE}}$ & $44.2^{B}$ & $1857.2^{c}$ & 0.93 & 66.7 & $37.0^{c}$ & 4.0 & $10.0^{C}$ & 2.0 \\
\hline $\begin{array}{l}\text { Pseudomonas } \\
\text { sp. Gamma-81 }\end{array}$ & & $500.0^{\mathrm{FG}}$ & $0.0^{\mathrm{E}}$ & $26.0^{\mathrm{DE}}$ & $526.0^{\mathrm{EF}}$ & 0.26 & 90.6 & $13.2^{F}$ & 3.0 & $0.0^{\mathrm{D}}$ & 0.0 \\
\hline P. tolaasii & & $564.0^{\mathrm{FG}}$ & $0.0^{\mathrm{E}}$ & $29.2^{\mathrm{CD}}$ & $593.2^{\mathrm{EF}}$ & 0.30 & 89.4 & $16.0^{\mathrm{EF}}$ & 3.0 & $3.0^{\mathrm{D}}$ & 2.0 \\
\hline P. chlororaphis & & $428.0^{\mathrm{FGH}}$ & $0.0^{\mathrm{E}}$ & $16.0^{\mathrm{FG}}$ & $444.0^{\mathrm{EFG}}$ & 0.22 & 92.0 & $13.0^{\mathrm{F}}$ & 3.0 & $0.0^{\mathrm{D}}$ & 0.0 \\
\hline P. mosselii. & & $396.0^{\mathrm{FGH}}$ & $0.0^{\mathrm{E}}$ & $15.0^{G}$ & $411.0^{\mathrm{EFG}}$ & 0.21 & 92.6 & $12.8^{\mathrm{F}}$ & 3.0 & $0.0^{\mathrm{D}}$ & 0.0 \\
\hline Control(+) & & $5412.0^{\mathrm{A}}$ & $87.4^{\mathrm{A}}$ & $74.6^{\mathrm{A}}$ & $5574.4^{\mathrm{A}}$ & 2.79 & 0.0 & $63.8^{\mathrm{A}}$ & 4.0 & $15.8^{\mathrm{A}}$ & 3.0 \\
\hline Oxamyl & & $244.0^{\mathrm{GH}}$ & $16.2^{\mathrm{CD}}$ & $27.8^{\mathrm{CD}}$ & $288.0^{\mathrm{FG}}$ & 0.14 & 94.8 & $21.6^{\mathrm{DE}}$ & 3.0 & $10.0^{C}$ & 2.0 \\
\hline P. japonica & \multirow{9}{*}{$\begin{array}{l}\text { M. incognita }+A \text {. } \\
\text { tumefaciens }\end{array}$} & $1216.0^{\mathrm{DE}}$ & $10.0^{\mathrm{CDE}}$ & $31.6^{\mathrm{CD}}$ & $1257.6^{\mathrm{D}}$ & 0.63 & 72.4 & $31.4^{C}$ & 4.0 & $12.0^{B C}$ & 3.0 \\
\hline B. megaterium & & $608.0^{\mathrm{FG}}$ & $0.0^{\mathrm{E}}$ & $27.0^{\mathrm{D}}$ & $635.0^{\mathrm{EF}}$ & 0.32 & 86.1 & $23.2^{\mathrm{D}}$ & 3.0 & $0.0^{\mathrm{D}}$ & 0.0 \\
\hline $\begin{array}{l}\text { Pseudomonas } \\
\text { sp. Gamma-81 }\end{array}$ & & $1348.0^{\mathrm{D}}$ & $19.4^{c}$ & $35.2^{c}$ & $1402.6^{\mathrm{D}}$ & 0.70 & 69.2 & $36.0^{c}$ & 4.0 & $3.0^{\mathrm{D}}$ & 2.0 \\
\hline P. tolaasii & & $436.0^{\mathrm{FG}}$ & $0.0^{\mathrm{E}}$ & $25.8^{\mathrm{DE}}$ & $461.8^{\mathrm{EF}}$ & 0.23 & 89.9 & $22.2^{\mathrm{DE}}$ & 3.0 & $0.0^{\mathrm{D}}$ & 0.0 \\
\hline P. chlororaphis & & $486.0^{\mathrm{FG}}$ & $0.0^{\mathrm{E}}$ & $23.8^{\mathrm{DEF}}$ & $509.8^{\mathrm{EF}}$ & 0.25 & 88.8 & $21.4^{\mathrm{DE}}$ & 3.0 & $0.0^{\mathrm{D}}$ & 0.0 \\
\hline P. mosselii. & & $324.0^{\mathrm{GH}}$ & $0.0^{\mathrm{E}}$ & $18.4^{\mathrm{EFG}}$ & $342.4^{\mathrm{FG}}$ & 0.17 & 92.5 & $11.0^{\mathrm{F}}$ & 3.0 & $0.0^{\mathrm{D}}$ & 0.0 \\
\hline Control(+) & & $4456.0^{B}$ & $59.6^{\mathrm{B}}$ & $44.8^{\mathrm{B}}$ & $4560.4^{B}$ & 2.28 & 0.0 & $53.0^{B}$ & 4.0 & $13.4^{\mathrm{AB}}$ & 3.0 \\
\hline Control(-) & & $0.0^{\mathrm{H}}$ & $0.0^{\mathrm{E}}$ & $0.0^{\mathrm{H}}$ & $0.0^{G}$ & 0.0 & 0.0 & $0.0^{G}$ & 0.0 & $0.0^{\mathrm{D}}$ & 0.0 \\
\hline Healthy plants & & $0.0^{\mathrm{H}}$ & $0.0^{\mathrm{E}}$ & $0.0^{\mathrm{H}}$ & $0.0^{G}$ & 0.0 & 0.0 & $0.0^{G}$ & 0.0 & $0.0^{\mathrm{D}}$ & 0.0 \\
\hline
\end{tabular}

Means in the same column shared a letter are not significantly different ( $p \leq 0.05$ ); RF = final population in treatment/2000; Red\% (reductions in nematode population\% $=\left[\left(\mathrm{Pf}_{\mathrm{c}}-\mathrm{Pf}_{\mathrm{t}}\right) / \mathrm{Pf}_{\mathrm{c}}\right] \times 100$ where $\mathrm{Pf}_{\mathrm{c}}=$ final population in control and $\mathrm{Pf}_{\mathrm{t}}=$ final population $(\mathrm{Pf})$ in treatment; $\mathrm{RGI}$ or El was determined according to the scale given by Taylor and Sasser (1978)

growth parameters of tomato (shoot and root length, shoot and root fresh weight, total fresh weight of plant, and total dry weight of plant) than the negative control and healthy plants (Table 8). The only exception was found in case of Pseudomonas sp. Gamma-81, when used against $M$. incognita and the mixed infection (A. tumefaciens and $M$. incognita), where growth parameters of tomato were decreased. On the other hand, A. tumefaciens (positive control treatment) increased all growth parameters than the negative control and healthy plants, while $M$. incognita (positive control treatment) decreased all growth parameters than the healthy plants.

When the tested $\mathrm{HCN}$-producing rhizobacteria were used against $A$. tumefaciens, all isolates increased shoot weight, root length, total fresh weight, and total dry weight of tomato plants than the positive control treatment $(A$. tumefaciens). The only exception was recognized in case of root length and total fresh weight in $P$. japonica isolate treatment. The isolate of $P$. japonica recorded root length and total fresh weight of $28.2 \mathrm{~cm}$ and $49.3 \mathrm{~g}$ compared to $A$. tumefaciens (positive control treatment) that recorded 29.7 $\mathrm{cm}$ and $52.9 \mathrm{~g}$, respectively. Also, $P$. japonica, $B$. megaterium, and $P$. chlororaphis increased shoot length compared to the positive control treatment (A. tumefaciens) and recorded 58.4, 56.3, and $61.8 \mathrm{~cm}$, respectively, while Pseudomonas sp. Gamma-81, P. tolaasii, and P. mosselii decreased shoot length than the positive control treatment $(A$. tumefaciens) and recorded 52.5, 51.7, and $54.3 \mathrm{~cm}$, respectively. The positive control treatment ( $A$. tumefaciens) recorded shoot length of $55.0 \mathrm{~cm}$. Meanwhile, root weight of tomato plants was increased by using $P$. mosselii against $A$. tumefaciens than the positive control treatment (A. tumefaciens) and recorded $18.0 \mathrm{~g}$. At the same time, root weight of tomato plants was decreased by using $P$. japonica, $B$. megaterium, Pseudomonas sp. Gamma-81, P. tolaasii, and P. chlororaphis, which recorded 8.3, 12.6, 12.9, 14.0, and 11.0 $\mathrm{g}$, respectively. The positive control treatment (A. tumefaciens) recorded root weight of $14.8 \mathrm{~g}$.

Meanwhile, the tested $\mathrm{HCN}$-producing rhizobacteria against $M$. incognita increased all growth parameters of tomato plants than the positive control treatment $(M$. incognita). The only exception was found in case of Pseudomonas sp. Gamma-81 that decreased all growth parameters of tomato plants. 
Table 8 Effect of HCN-producing rhizobacteria on growth parameters of tomato plants infected with of Agrobacterium tumefaciens and/or Meloidogyne incognita after 45 days of inoculation

\begin{tabular}{|c|c|c|c|c|c|c|c|}
\hline \multirow[t]{2}{*}{ Treatment } & \multirow[t]{2}{*}{ Pathogen } & \multicolumn{6}{|c|}{ growth parameters } \\
\hline & & $\begin{array}{l}\text { Shoot length } \\
(\mathrm{cm})\end{array}$ & $\begin{array}{l}\text { Shoot weight } \\
\text { (g) }\end{array}$ & $\begin{array}{l}\text { Root length } \\
(\mathrm{cm})\end{array}$ & $\begin{array}{l}\text { Root weight } \\
\text { (g) }\end{array}$ & $\begin{array}{l}\text { Total fresh weight } \\
\text { (g) }\end{array}$ & $\begin{array}{l}\text { Total dry weight } \\
\text { (g) }\end{array}$ \\
\hline P. japonica & \multirow[t]{8}{*}{ A. tumefaciens } & $58.4^{B-F}$ & $41.0^{A B C}$ & $28.2^{\mathrm{E}-1}$ & $8.3^{\mathrm{E}-1}$ & $49.3^{A-F}$ & $24.8^{A B}$ \\
\hline B. megaterium. & & $56.3^{C-G}$ & $46.5^{\mathrm{A}}$ & $37.7^{A-D}$ & $12.6^{B-F}$ & $59.1^{\mathrm{A}}$ & $22.5^{A-D}$ \\
\hline $\begin{array}{l}\text { Pseudomonas sp. } \\
\text { Gamma-81 }\end{array}$ & & $52.5^{\mathrm{E}-1}$ & $40.8^{\mathrm{ABC}}$ & $30.5^{\mathrm{C}-\mathrm{H}}$ & $12.9^{B-E}$ & $53.7^{A-E}$ & $19.8^{A-E}$ \\
\hline P. tolaasii & & $51.7^{F-J}$ & $42.4^{\mathrm{ABC}}$ & $39.3^{A B}$ & $14.0^{\mathrm{ABC}}$ & $56.4^{\mathrm{ABC}}$ & $23.5^{\mathrm{ABC}}$ \\
\hline P. chlororaphis & & $61.8^{\mathrm{BCD}}$ & $46.9^{\mathrm{A}}$ & $43.8^{\mathrm{A}}$ & $11.0^{\mathrm{B}-\mathrm{H}}$ & $57.9^{\mathrm{AB}}$ & $25.6^{\mathrm{AB}}$ \\
\hline P. mosselii & & $54.3^{\mathrm{D}-\mathrm{H}}$ & $43.1^{\mathrm{AB}}$ & $39.0^{\mathrm{AB}}$ & $18.0^{\mathrm{A}}$ & $61.1^{\mathrm{A}}$ & $27.2^{\mathrm{A}}$ \\
\hline Control(+) & & $55.0^{C-G}$ & $38.1^{\mathrm{BCD}}$ & $29.7^{\mathrm{D}-\mathrm{H}}$ & $14.8^{\mathrm{AB}}$ & $52.9^{A-E}$ & $18.4^{B-F}$ \\
\hline Control(-) & & $37.8^{\mathrm{KL}}$ & $11.2^{1}$ & $21.3^{1 J}$ & $4.0^{11}$ & $15.2^{\mathrm{JK}}$ & $6.8^{\mathrm{G}}$ \\
\hline P. japonica & \multirow[t]{8}{*}{ M. incognita } & $58.8^{B-F}$ & $31.2^{\mathrm{DEF}}$ & $34.3^{B-E}$ & $11.6^{B-G}$ & $42.8^{\mathrm{EFG}}$ & $25.5^{A B}$ \\
\hline B. megaterium. & & $57.3^{C-F}$ & $34.7^{\mathrm{CDE}}$ & $32.8^{B-G}$ & $9.5^{\mathrm{C}-\mathrm{H}}$ & $44.2^{D-G}$ & $21.0^{A-D}$ \\
\hline $\begin{array}{l}\text { Pseudomonas sp. } \\
\text { Gamma-81 }\end{array}$ & & $43.7^{\mathrm{JKL}}$ & $16.9^{\mathrm{HI}}$ & $23.7^{H I J}$ & $6.5^{\mathrm{HIJ}}$ & $23.4^{1 \mathrm{JK}}$ & $11.5^{\mathrm{FG}}$ \\
\hline P. tolaasii & & $60.5^{B-E}$ & $37.2^{B-E}$ & $32.2^{B-G}$ & $7.4^{\mathrm{GHI}}$ & $44.6^{C-G}$ & $22.0^{\mathrm{A}-\mathrm{D}}$ \\
\hline P. chlororaphis & & $63.2^{\mathrm{ABC}}$ & $30.1^{\mathrm{EF}}$ & $34.5^{B-E}$ & $7.2^{\mathrm{G}-J}$ & $37.3^{\mathrm{G}-\mathrm{H}}$ & $26.4^{\mathrm{A}}$ \\
\hline P. mosselii & & $54.7^{D-G}$ & $26.5^{\mathrm{FG}}$ & $29.0^{E-1}$ & $7.9^{F-1}$ & $34.4^{\mathrm{GHI}}$ & $27.0^{A}$ \\
\hline Control(+) & & $45.5^{1 \mathrm{JK}}$ & $17.6^{\mathrm{HI}}$ & $25.0^{G-J}$ & $6.7^{\mathrm{HIJ}}$ & $24.3^{1 \mathrm{IJK}}$ & $15.0^{\mathrm{DEF}}$ \\
\hline Oxamyl & & $48.0^{G-J}$ & $20.1^{\mathrm{GH}}$ & $28.9^{E-1}$ & $7.3^{\mathrm{G}-J}$ & $27.4^{\mathrm{HI}}$ & $16.0^{C-F}$ \\
\hline P. japonica & \multirow{9}{*}{$\begin{array}{l}\text { A. tumefaciens } \\
\text { and } \\
\text { M. incognita }\end{array}$} & $71.0^{\mathrm{A}}$ & $42.8^{\mathrm{AB}}$ & $30.0^{C-H}$ & $12.9^{B-E}$ & $55.7^{A-D}$ & $26.8^{\mathrm{A}}$ \\
\hline B. megaterium. & & $58.0^{B-F}$ & $30.8^{\mathrm{DEF}}$ & $39.2^{A B}$ & $10.0^{B-H}$ & $40.8^{\mathrm{FG}}$ & $18.5^{\mathrm{BF}}$ \\
\hline $\begin{array}{l}\text { Pseudomonas sp. } \\
\text { Gamma-81 }\end{array}$ & & $36.0^{L}$ & $11.0^{1}$ & $17.5^{\jmath}$ & $2.5^{\jmath}$ & $13.5^{\mathrm{K}}$ & $5.5^{\mathrm{G}}$ \\
\hline P. tolaasii & & $61.5^{\mathrm{BCD}}$ & $39.4^{A B C}$ & $29.3^{E-1}$ & $13.2^{A-D}$ & $52.6^{A-F}$ & $20.0^{\mathrm{A}-\mathrm{E}}$ \\
\hline P. chlororaphis & & $65.8^{\mathrm{AB}}$ & $36.2^{B-E}$ & $33.3^{B-F}$ & $8.6^{\mathrm{D}-1}$ & $44.8^{C-G}$ & $18.1^{B-F}$ \\
\hline P. mosselii & & $57.0^{C-F}$ & $38.3^{\mathrm{BCD}}$ & $29.0^{E-1}$ & $8.0^{F-1}$ & $46.3^{B-G}$ & $24.0^{\mathrm{A} \mathrm{B}}$ \\
\hline Control(+) & & $54.3^{\mathrm{D}-\mathrm{H}}$ & $36.5^{B-E}$ & $37.8^{\mathrm{ABC}}$ & $9.7^{\mathrm{C}-\mathrm{H}}$ & $46.2^{B-G}$ & $18.0^{B-F}$ \\
\hline Control(-) & & $37.8^{\mathrm{KL}}$ & $11.2^{1}$ & $21.3^{1 J}$ & $4.0^{11}$ & $15.2^{\mathrm{JK}}$ & $6.8^{\mathrm{G}}$ \\
\hline Healthy plants & & $46.0^{\mathrm{H}-\mathrm{K}}$ & $18.5^{\mathrm{HI}}$ & $25.3^{\mathrm{F}-J}$ & $7.0^{\mathrm{G}-J}$ & $25.5^{\mathrm{HI}}$ & $12.4^{\mathrm{EFG}}$ \\
\hline
\end{tabular}

Means in the same column shared a letter are not significantly different $(p \leq 0.05)$

HCN-producing rhizobacteria gave various results when used against mixed infection with $A$. tumefaciens and $M$. incognita. The isolates of $P$. japonica and $P$. tolaasii increased all plant growth parameters of tomato than the positive control treatment (A. tumefaciens and $M$. incognita), the only exception was found in case of root length. The isolate of $B$. megaterium increased all tomato plant growth parameters than the positive control treatment (A. tumefaciens and $M$. incognita), the only exception was found in case of shoot weight and total fresh weight. Also, P. mosselii increased all tomato plant growth parameters than positive control treatment (A. tumefaciens and M. incognita), except the root length and root weight. Meanwhile, Pseudomonas sp. Gamma81 decreased all tomato plant growth parameters than the positive control treatment. Also, P. chlororaphis decreased shoot weight, root length, root weight and total fresh weight and increased shoot length and total dry weight compared to the positive control treatment.

In addition to its ability to promote the growth of plants indirectly by inhibiting the growth of pathogens, it is well established that some Pseudomonas spp. can produce substances that promote the growth of plants directly as indole-3-acetic acid (IAA), siderophores that chelate iron, and phosphatases that solubilize phosphorus (Rai et al. 2017). Moreover, Bacillus spp. beside its ability to act as a biological agent by producing $\mathrm{HCN}$ and antibiotics, they also produce phytohormones like IAA and GA, increases uptake of nutrients like phosphate and iron by siderophore production, produces ammonia, protects cell from oxidative damage by producing catalase enzyme and exhibited tolerance 
against heavy metal and salinity (Rayavarapu and Padmavathi 2016). More interesting, it has been recently found that A.tumefaciens isolate, isolated from nodules of plants growing in zinc-lead mine tailings, showed high metal resistance and enhanced the growth of plants in a metal-contaminated environment (Hao et al. 2012). On the other hand, $M$. incognita decreased the plants growth, causing loss in plant parameters that may be directly correlated with the multiplication of the nematodes (Anver and Alam 1989). The results herein showed that A. tumefaciens caused an increment in all plant parameters compared to the negative control and healthy plants, while $M$. incognita decreased all plant parameters than the healthy plants.

Finally, although all obtained isolates were recovered locally from rhizosphere soils of some plants and had a role in biocontrol of $A$. tumefaciens and $M$. incognita, but $P$. japonica and $P$. tolaasii cannot be used in this field, until being sure that these strains are not pathogenic to humans and animals. In this regard, it has been reported that $P$. japonica is a novel species in the sub-cluster of $P$. putida group, isolated from an activated sludge and more recently reported as a novel cause of skin bacteremia and soft tissue infection (Coomes et al. 2018). P. tolaasii is a species of gram-negative bacteria causing bacterial blotch on cultivated mushrooms (Agaricus bisporus) under some environmental conditions (Soler-Rivas et al. 1999). Thus, further field trials and pilot experimentation are suggested.

\section{Conclusion}

Six isolates of $\mathrm{HCN}$-producing rhizobacteria were recovered locally from rhizosphere soils of some plants in Egypt. These HCN-producing rhizobacteria were able to inhibit growth of Agrobacterium tumefaciens and affect viability of Meloidogyne incognita juveniles in vitro. The isolates decreased the weight and number of galls produced by $A$. tumefaciens on tomato plants, regardless to the presence of M. incognita. The $6 \mathrm{HCN}$ producers decreased the population of $M$. incognita and the number of nematode galls produced on tomato when used against $M$. incognita, and a similar effect was achieved against mixed infection with $M$. incognita and $A$. tumefaciens. The HCN-producing rhizobacteria in the presence of $A$. tumefaciens and/or M. incognita caused obvious increment in all growth parameters of tomato plant. Further investigations are still needed.

\section{Acknowledgements}

The authors would like to thank Dr. Nabil S. Farag (Department of Plant Bacterial Disease, Plant Pathology Research Institute, Agriculture Research Center, Giza, Egypt) and Dr. Fatma Abdel Mohsen Mostafa (Agric. Zoology Dept., Fac. of Agric., Mansoura University, Egypt) for reviewing the manuscript.

\section{Authors' contributions}

AFA conceived the idea. All of the authors of this manuscript contributed equally to the design and/or execution of the experiments described in the manuscript. All authors read and approved the final manuscript.
Funding

Not applicable.

\section{Availability of data and materials}

The datasets used and/or analyzed during the current study are available from the corresponding author on reasonable request.

Ethics approval and consent to participate

Not applicable.

\section{Consent for publication}

Not applicable.

\section{Competing interests}

The authors declare that they have no competing interests.

Received: 12 February 2019 Accepted: 7 June 2019

Published online: 26 June 2019

\section{References}

Abd El-Ghany H, Moussa Z, Salem EA, Abd El-Rahman AF (2017) Management of potato soft rot by gamma irradiation. Arab J Nucl Sci Appl 50(3):159-173

Abd El-Rahman AF (2012) Biological control of crown gall disease of stone fruit trees. Ph.D. Thesis, Faculty of Agriculture, Ain Shams University, Egypt, 123 pp

Abd El-Rahman AF, Shaheen HA (2016) Biological control of the brown rot of potato, Ralstonia solanacearum and effect of bacterization with antagonists on promotion of potato growth. Egyptian J Biol Pest Control 26(4):733-739

Abdel-Salam MS, Ameen HH, Soliman GM, Elkelany US, Asar AM (2018) Improving the nematicidal potential of Bacillus amyloliquefaciens and Lysinibacillus sphaericus against the root-knot nematode Meloidogyne incognita using protoplast fusion technique. Egyptian J Biol Pest Control 28:31

Alemu F (2016) Isolation of Pseudomonas flurescens from rhizosphere of faba bean and screen their hydrogen cyanide production under in vitro study, Ethiopia. Am J Life Sci 4(2):13-19

Anver S, Alam MM (1989) Effect of root-knot and reniform nematodes on plant growth and bulk-density of plant residues of pigeonpea. Biol Wastes 30(4):245-250

Coomes E, Silverstein WK, Zipursky JS, Shojania K (2018) Pseudomonas japonica: a novel cause of bacteremia and skin and soft tissue infection. Infect Dis Clin Pract 26(5):e43-e44

Eden PA, Schmidt TM, Blakemore RP, Pace NR (1991) Phylogenetic analysis of Aquaspirillum magnetotacticum using polymerase chain reaction-amplified 16 rRNA-specific DNA. Int J Syst Bacteriol 41(2):324-325

Farag SMA, Elhalag KMA, Hagag MH, Khairy AM, Ibrahim HM, Saker MT, Messiha NAS (2017) Potato bacterial wilt suppression and plant health improvement after application of different antioxidants. J Phytopathol 165:522-537

Hao X, Xie P, Johnstone L, Miller SJ, Rensing C, Wei G (2012) Genome sequence and mutational analysis of plant-growth-promoting bacterium agrobacterium tumefaciens CCNWGS0286 isolated from a zinc-lead mine tailing. Appl Environ Microbiol 78(15):5384-5394

Ibrahim DSS, Nour El-Deen AH, Khalil AE, Mostafa FAM (2013) Induction of systemic resistance in sugar-beet infected with Meloidogyne incognita by humic acid, hydrogen peroxide, thiamine and two amino acids. Egypt J Agronematol 12(1):22-41

Kifle MH, Laing MD (2016) Isolation and screening of bacteria for their diazotrophic potential and their influence on growth promotion of maize seedlings in greenhouses. Front Plant Sci 6:1225

Lanteigne C, Gadkar VJ, Wallon T, Novinscak A, Filion M (2012) Production of DAPG and HCN by Pseudomonas sp. LBUM300 contributes to the biological control of bacterial canker of tomato. Phytopathology 102(10):967-973

Lukkani NJ, Reddy ECS (2014) Evaluation of plant growth promoting attributes and biocontrol potential of native fluorescent Pseudomonas sp. against Aspergillus niger causing collar rot of ground nut. Int J Plant, Animal Environ Sci 4:256-262

Mostafa FAM, Khalil AE, Nour El Deen AH, Ibrahim DS (2014) Induction of systemic resistance in sugar- beet against root-knot nematode with commercial products. J Plant Pathol Microb 5:236

Pulawska J (2010) Crown gall of stone fruits and nuts, economic significance and diversity of its causal agents: tumorigenic Agrobacterium spp. J Plant Pathol 92:587-598 
Rai A, Rai PK, Singh S (2017) Exploiting beneficial traits of plant-associated fluorescent pseudomonads for plant health. In: Singh JS, Seneviratne G (eds) Agro - environmental sustainability Vol. (1). Springer, Cham, pp 19-41 Rayavarapu VGB, Padmavathi T (2016) Bacillus sp as potential plant growth promoting rhizobacteria. Int J Adv Life Sci 9(1):29-36

Reetha AK, Pavani SL, Mohan S (2014) Hydrogen cyanide production ability by bacterial antagonist and their antibiotics inhibition potential on Macrophomina Phaseolina (Tassi.) Goid. Int J Curr Microbiol App Sci 3(5):172-178

Rijavec T, Lapanje A (2016) Hydrogen cyanide in the rhizosphere: not suppressing plant pathogens, but rather regulating availability of phosphate. Front Microbiol 7:1785

Rubio-Cabetas M, Minot J, Voisin R, Esmenjaud D (2001) Interaction of root-knot nematodes (RKN) and the bacterium Agrobacterium tumefaciens in roots of Prunus cerasifera: evidence of the protective effect of the Ma RKN resistance genes against expression of crown gall symptoms. Eur J Plant Path 107:433-441

Siddiqui IA, Shaukat SS, Sheikh IH, Khan A (2006) Role of cyanide production by Pseudomonas fluorescens CHAo in the suppression of root-knot nematode, Meloidogyne javanica in tomato. World J Microbiol Biotechnol 22:641-650

Soler-Rivas C, Jolivet S, Arpin N, Olivier JM, Wichers HJ (1999) Biochemical and physiological aspects of brown blotch disease of Agaricus bisporus. FEMS Microbiol Rev 23(5):591-614

Taylor AL, Sasser JN (1978) Biology, identification and control of root-knot nematodes (Meloidogyne species). Department of Plant Pathology, North Carolina State University, United States Agency for International Development. Raleigh, North Carolina, USA, vii + 111 pp

Tolba IH, Soliman MA (2013) Efficacy of native antagonistic bacterial isolates in biological control of crown gall disease in Egypt. Ann Agric Sci 58(1):43-49

\section{Publisher's Note}

Springer Nature remains neutral with regard to jurisdictional claims in published maps and institutional affiliations.

\section{Submit your manuscript to a SpringerOpen ${ }^{\circ}$ journal and benefit from:}

- Convenient online submission

- Rigorous peer review

- Open access: articles freely available online

- High visibility within the field

- Retaining the copyright to your article

Submit your next manuscript at $\boldsymbol{\nabla}$ springeropen.com 